\title{
Fuel Subsidy Removal And The Ubiquity Of Hardship In Nigeria: President Buhari And Lessons From King Rehoboam
}

\author{
Ugumanimn Bassey Obo \\ Department of Political Science \\ University of Calabar, Calabar - Nigeria \\ Jacob Iba Omenka \\ Department Of Political Science \\ Benue State University, Makurdi- Nigeria \\ Tabitha Venenge Agishi \\ Department Of Political Science \\ Benue State University, Makurdi- Nigeria \\ Maurice Ayodele Coker \\ Department Of Political Science \\ University Of Calabar, Calabar - Nigeria
}

\begin{abstract}
This essay specifically focuses attention on one of the policies of the government of Muhammadu Buhari, that is, the policy of removal of fuel subsidy and the increase of pump price of petrol in Nigeria, and the dire consequences it has had for the wellbeing of the people. It is argued that given the size of the pump price increase, the way it was enforced, and the enormous increases in the costs of goods and services which it has engendered, President Buhari appears to be in the same league with the Biblical King Rehoboam who presided over an era of unprecedented cruelty in Israel. It is also reasoned that if well-articulated, managed and targeted, subsidy can serve as a policy instrument for the promotion of the public good. This paper also stresses the need for Nigeria to urgently stop the importation of refined petroleum products and begin to refine its products domestically.
\end{abstract}

Keywords: Subsidy, subsidy removal, hardship, Rehoboam; fuel, petrol

\section{INTRODUCTION}

There were hopes in 1999 that the socio-economic problems plaguing the nation then would be washed by civilians. There is no such hope anymore as the problems have refused to go away. A grim picture pervades the economic skyline and the average Nigerian has only one description: poor, under-nourished, poorly sheltered, unemployed and where employed, poorly remunerated.

- Nkeneke Efo (2002: 21-22)

The present socio-economic condition of an average Nigerian is far worse than the situation captured in the above view which was expressed fifteen years ago. In addition to the challenges listed above, excruciating hardship, hunger (starvation in some cases), misery and unprecedented high cost of living, among others, have become the key pillars of Nigeria's socioeconomic architecture. Indeed, to say that Nigerians are economically hurting at this moment is no exaggeration; to state that most Nigerians have never had it this economically difficult in 
their lifetime is not an over-statement; the fact that most Nigerians are out of work and go to bed hungry now is no longer news; the pains are palpable in the voices and faces of everyday Nigerians on the streets and in the work and market places across the land (Ukah, 2016).

In one of his essays, Ibi Ajayi (2003: 17) had stated - many years before the emergence of the current Buhari-led administration - that the economy had not improved, and that poverty was becoming so entrenched that many could not feed their families well. In his words, "food has assumed such a big space in our national psyche that anyone who is able to manage three square meals is considered to have performed a feat." That was over a decade ago; today, due to the astronomical costs of goods and services, one decent meal in a day has become a very rare phenomenon in most homes in Nigeria. The self-dignity of most Nigerians has been grossly attenuated by the policies and programmes of those who run the Nigerian state; for a person who cannot properly feed himself/herself is not worthy of the epithet "man/woman".

While relying on the work of Freire (1970), Ojekheta (2010: 268) has reasoned that human existence has been classified into two categories: those who merely exist and those who really exist; those who merely exist suffer true humanization. True humanization, the argument goes, takes place only when each person becomes conscious of the social forces working upon him or her, reflects upon these forces, and becomes capable of transforming the world. As things currently stand in Nigeria, it is clear that most Nigerians merely exist. Indeed, as Obo, Coker and Omenka (2014: 71) put it, Nigeria is a country of paradoxes: it makes billions of dollars annually as revenue from only one resource (i.e. crude oil), yet millions of its people are wretched. In fact, over seventy percent of its population are said to be enmeshed in extreme poverty.

This essay is focused on the removal (or withdrawal) of fuel subsidy by the Buhari regime, and how this policy has greatly worsened the socio-economic conditions of already long-suffering Nigerians. There is no doubt that "the performance of an administration can be assessed not by relying on the propagandistic effusions of its spokespersons, but by critically examining the results or outcomes of the policies and programmes implemented by the administration, and how these have impinged on the welfare of the citizenry" (Obo and Abua, 2008: 304). It is by examining the consequences of the Buhari-led government's policy of fuel subsidy removal that the present crippling economic hardship in the country can be properly situated. In fact, the pains inflicted on the Nigerian people by this class-inspired policy of the Buhari regime remind one of the cruel reign of Rehoboam, one of the kings who led the Israelites before the birth of Jesus Christ. We shall return to this point later.

This paper also draws attention to the fact that by increasing the price of petrol - through the withdrawal of government subsidy - President Muhammadu Buhari, his government and his party (All Progressive Congress) have failed to fulfil one of the major promises they made to Nigerians during the campaign for the 2015 General Elections. During the campaign, Buhari had pledged to reduce the cost of petrol by 50\%; in January 2015 just before the elections, Buhari, while reacting to the pump price of petrol in the country, said: "it is disturbing that in spite of the fall in the global price of crude oil, Nigerians still buy petroleum products at pump prices as if the global price of crude oil had remained at \$100(USD) per barrel" (Boladale, 2016). In 2015, President Buhari reportedly said: "I have received many literatures on the need to remove subsidies, but much of it has no depth"; he continued: "when you touch the price of petroleum products, that has the effect of triggering price rises on transportation, food and rents. That is for those who earn salaries, but there are many who are jobless and will be affected by it" (George, 2015). 
In a national address to mark his government's one-year anniversary, President Buhari declared: "for too long, ours has been a society that neglects the poor and victimizes the weak. A society that promotes profits and growth over development and freedom..." (www.punchng.com/text-president...). But the huge increase in the pump price of petrol by the government not only neglects and emasculates the poor, it also compounds their misery. Moreover, the policy promotes and enhances the profits of oil dealers and other actors in Nigeria's oil industry and dwarfs the economic potentials and fortunes of the masses. President Buhari and Nigeria's political elites need to realize that in the words of John Fitzgerald Kennedy (cited in Ogundipe, 2009: 57), "a society that cannot care for the many who are poor cannot save the few who are rich."

This paper is an academic endeavour totally in support of the toiling Nigerian masses, and it is made up of four sections. Following this introduction is section two which contains a few conceptual and theoretical perspectives on the term "subsidy". In section three, the untold hardship unleashed on Nigerians by the policy of subsidy removal is highlighted, and a particular similarity is also established between this policy and the actions of the inhuman era of the biblical King Rehoboam in Israel. Section four contains the conclusion.

\section{SUBSIDY: SOME CONCEPTUAL AND THEORETICAL PERSPECTIVES}

In Nigeria, because of how often the government fiddles with the price regime of petroleum products, and the catastrophic impact this has always had on the lives of the majority of the people (the only exceptions being when prices were reduced by the administrations of late President Umaru Yar'Adua and President Goodluck Jonathan), the term "subsidy" has become an emotive concept and a buzzword in socio-economic analyses. Indeed, to use the words of Jurgen Osterhammel and Niels Peterson (cited in Exenberger, 2013: 11), one already needs "pathfinder literature" to master this intellectual cornucopia.

The point has been made that definition is often the impression of the person defining a concept; the person defining a concept is usually a product of a particular socialization process based on a unique intellectual tradition, and his explanation of the concept is largely influenced by such tradition (Ujo, 2001 cited in Obo and Abua, 2008: 299). A number of views and intellectual positions have been expressed and articulated on the concept "subsidy". A few of these shall be highlighted at this point.

According to Ehi Oyabure (2011), simply put, subsidy is benefit usually given by government to group or individuals in form of price reduction to remove some types of burden and it is often considered to be of public interest. In Nigeria, in Oyabure's view, fuel subsidy payment only applies when the landing cost of a petroleum product based on the import parity exceeds the approved ex-depot price for the product. It has been opined that subsidy, in an economic sense, exists when consumers of a given commodity are assisted by the government to pay less than the prevailing market price of same. In respect of fuel subsidy, the argument goes, it means that consumers would pay less than the pump price per litre of petroleum product; and on the other hand, it is reasoned, fuel subsidy could be described as the difference between the actual market price of petroleum products per litre and what the final consumers are paying for the same product (Majekodunmi, 2013: 77).

In a very interesting study, Khalil Timamy (2007: 552-554) dichotomizes between "good subsidies" and "bad subsidies", and critically exposes the enormous hypocrisy of westerndominated Bretton Woods institutions (i.e. the International Monetary Fund and the World Bank) in their anti-subsidy recommendations to underdeveloped states whereas the industrialized countries of the North which control and dominate these institutions operate 
different forms of subsidy schemes and programmes for the welfare of their own people. He argues that the central message which developing countries have heard and which the Bretton Woods institutions have drummed deafeningly, incessantly and intentionally, is that subsidies are a diabolical device not to be touched by a ten foot pole. He also points out that their condemnation has been wholesale and total, and as a matter of fact, they have demonized this instrument and given it a horrible negative publicity. Clearly, in Timamy's view, these institutions have made no attempt to appreciate the spectral heterogeneity of this measure nor draw a distinction between good and bad subsidies.

Furthermore, Timamy contends that a cursory glance at the Western policy landscape has revealed that subsidies have been a pervasive feature of economic management in industrialized countries, and from that experience, many observers have succeeded in distinguishing between good and bad subsidies. In other words, according to Timamy, subsidies are like a spectrum; there are those which are flagrantly protectionist and economically harmful, those that are significantly environmentally helpful, and those that promote the growth of techno-industrial capabilities in strategic national sectors.

Timamy also points out that what Africa should have heard is that the particular forms which the subsidy support systems have taken in various countries are indefensible, archaic, ineffective, and inefficient, and that while some would need to be eliminated, others to be phased out gradually, and still others to be reformed, there loomed the pivotal need to overhaul the support structures in ways that do not compromise efficiency and equity considerations. He further opines that it should have been pointed out that the across-theboard price controls and generic protectionist regimes prevalent in Africa have increased government costs, pushed policy makers to raise taxes, and have, in many respects, been responsible for environmental degradation economy-wide. Moreover, he continues, they should have been reminded that, because many subsidies have been poorly targeted and lacked focus, the benefits meant to reach particular groups or sectors have flowed to unintended beneficiaries and invariably generated unforeseen incentives. Timamy also draws attention to the fact that while the Bretton Woods institutions cast subsidies in a very bad light and fail to address the issue of subsidy reforms and targeting, it is pitiful that African leaders have missed the opportunity to present relevant alternatives critical for promoting economic development; protecting domestic industries and jobs; generating domestic technological capabilities; and improving the lot of the poor. Sadly, on account of such glaring informational deficiencies, African leaders approached the whole issue within the "either-or" frame of reference. That subsidy structures could be reformed, renovated, re-designed, or be transformed by novel innovations, was not part of their vocabulary... (Timamy, 2007: 553).

On his part, Akpan Ekpo (2011: 27) is of the view that generally, subsidy represents an intervention in the market system because the market-determined price may not be fair and equitable particularly if the said product is essential in the functioning of the economy. Therefore, he argues, government intervenes to lower the price paid by buyers by either subsidizing the suppliers to reduce the cost of production, which would translate to lower prices for buyers and/or give the buyers enough money to enable them buy the product at a price lower than the equilibrium or market-determined prices.

Ekpo also points out that the removal of petroleum subsidy has become a recurring decimal in the menu of options for macroeconomic management of Nigeria's economy. In his opinion, most policy makers in government favour the removal of subsidy on the grounds that the wrong set of Nigerians (elite) are being subsidized at the expense of the poor, and because the removal would make resources available for the modernization of the oil sector and build the 
country's infrastructures, etc., labour, on the other hand, contends that subsidy removal would bring untold hardship on the masses who are already suffering from a lack of provision of basic social services and low wages, among others. It is Ekpo's position that the removal of subsidy suggests that the forces of demand and supply should determine the appropriate (equilibrium) petroleum pump price that would make both the buyers and suppliers of the product reasonably happy.

Subsidy can be seen as money that is paid by a government or an organisation to reduce the cost of producing goods and services so that their prices can be kept low; it can also be regarded as a device employed by government to assist either the consumer or producer to consume or produce certain commodities at prices below the prevailing market price. Moreover, subsidy can be described as a form of price manipulation where the government fixes the pump price for sale to consumers and pay the retailer the difference between the actual market price and the regulated or official price per litre (Hornby, 2005; Ovaga, 2010 and Iyobhebhe, 2012 cited in Anazodo, Ezenwile and Chukwurah, 2014: 90).

A subsidy has also been conceptualized as an assistance paid to a business for an entire economic sector or producers of goods and services, and most subsidies are government subventions given to industries that experience continuous unprofitable operations, but are of strategic importance to the nation (Sote, 2012: 20). According to Lekan Sote (2012: 20), environmental economists define subsidy as uncompensated environmental damage arising from the flow of goods and services, and in a budgetary context, it may be defined as "unrecovered costs" in the public provision of private goods. He observes that in Nigeria, the relevant state agency reimburses the differential between the unprofitable price that importers of petroleum products sell to the public and both the landing cost and the profit margin allowed. The differential is called petrol subsidy. Sote (2012: 20) also believes that there is a nexus between fuel subsidy and the economy. As he puts it,

transport, powered by fuel, conveys people and goods, and it must be factored into product costs. Therefore, if you have a regime of fuel subsidy, crops will be conveyed from the farm gate to consumers at more affordable costs. And from a well-fed, healthy and well-nourished citizenry you can get a productive workforce ...

According to Dolapo Ajala (2012), technically speaking, to subsidize means to set the price of a good or service below the equilibrium price; in other words, it means setting the price of a good below the cost of its production. That is a situation where Price is less than Marginal Cost as opposed to the optimum Price equals Marginal Cost. Thus, in his view, petrol subsidy is the act of government setting the prices of petroleum products below the cost of importing them. Ajala also reasons that in reality, subsidy is a tool used by governments around the world to gain competitive edge, enhance the welfare of certain aspects of its population and also to gain geo-strategic advantage.

The 1981 edition of Encyclopedia Britannica (cited in Ekpe, 2003: 38) regards subsidy as "a direct governmental payment, economic concession or special privilege granted to private firms, households or government units in order to promote public objectives." Subsidy has also been defined as "a payment by the government to producers or distributors in an industry to prevent the decline of the industry"; in addition to saving an industry from collapse, subsidies are also part of the vehicles of public policy with the primary aim of altering the undesirable outcomes which are associated with the operation of the free market economy (Todaro, 1977; Anyanwu, 1992 cited in Ekpe, 2003: 38). Ekpe (2003: 38-39) has shown that in developing economies, subsidy serves to promote economic growth and sustainable development. For 
instance, in his views, export subsidies tend to promote export trade while those on consumer goods help to keep down the cost of living. The point is also made that withdrawal of subsidy is simply the reverse of the granting of subsidy by the state; it is a situation whereby the state allows the price mechanism to regulate production and distribution of goods and services - in which case firms are given the free hand to organize production and fix prices based on the interplay between demand and supply; but this, unfortunately, is not always the case in Nigeria as prices are always arbitrarily fixed by the government (Ekpe, 2003: 39).

In a short essay, Omawumi Eyekpimi(2016) posits that subsidy is a grant paid by a government or a public organisation to an enterprise that benefits the citizens or members so that price of a commodity or service may be affordable, and this could be in the form of financial aids, interest-free loans, cash payments, or tax reductions with the aim of promoting socio-economic growth. Fuel subsidy, in Eyekpimi's words, is the Nigerian government's financial aid to Nigerians to enable the consumption of fuel at a cheaper rate, end unpredictable supply, and ensure stability in domestic fuel price.

It can be gleaned from the foregoing that in spite of the proliferation of conceptualizations on the subject, an essential point about subsidy is that it is the cost borne by a government or an organisation to facilitate the availability and affordability of a given good or service (or a number of goods or services). A subsidy scheme or programme is necessitated by the realization that if left unsupported, the majority of the people - because they are poor - cannot afford the costs of certain goods and/or services. It is instructive to note that in Nigeria, it is no longer news that over seventy percent of the people live below the poverty line.

\section{FUEL SUBSIDY REMOVAL AND MASS SUFFERING IN NIGERIA}

The Biblical narrative has it that one of the men who ruled the Jewish people was King Rehoboam. He was the ruler who publicly and unabashedly declared cruelty and brutality as his key instruments of governance. While addressing the people he was meant to govern, he unveiled the wicked and inhuman plans he had for them thus: "my father made your yoke heavy, but I will add to it; my father chastised you with whips, but I will chastise you with scorpions" (II Chronicles 10: 14).

By the manner and magnitude of the increase in the pump price of petrol, President Muhammadu Buhari appeared to be telling Nigerians that since his predecessors (especially Obasanjo, Babangida and Abacha) made life difficult for them, he's determined to make living in Nigeria a terribly nightmarish experience. Presently, as Farooq Kperogi (cited in Akinloye, 2017) has correctly observed, "every day in Nigeria is worse than the previous day, and there is no hope in sight". The current situation in the country has been caused mainly by the policies of the Buhari-led administration, one of which is the fuel subsidy removal. Indeed, with the present reality in Nigeria, it is difficult to challenge Jaye Gaskia's (2011) observation that it does not require a degree from Harvard or Oxford, or a career at the World Bank or in the banking and petroleum industries to be able to draw the conclusion that in an economy where provision of basic services and products depends on operation of petro-based generators to produce electricity needed; that in such an economy any increases in the prices of petroleum products, much less doubling of current prices, will have a serious, sustained, and deleterious effect on the livelihoods of tens of millions of Nigerians, and a calamitous if not clear catastrophic impact on the economy and social wellbeing of the country and her citizens.

Public policy is infested with special interest groups and private interests, and a policy that is sold as a public interest policy may not, in fact, be in the public interest; moreover, a policy that is, in fact, in public interest may be subverted against public interest (Uchendu, 2015: 43). This 
view is validated by the government's incessant fiddling with the price regime of petroleum products in Nigeria. In January 2012, "the regime of Goodluck Jonathan elevated official wickedness and sadism to higher levels by raising the price-per litre of petrol from sixty-five naira ( $\mathrm{N65)}$ to one hundred and forty-one naira (N141)" (Obo, Eteng and Coker, 2014: 91); but in May 2016, Muhammadu Buhari brought to bare his love and admiration for King Rehoboam and adopted official meanness and cruelty as instruments of statecraft by callously increasing the pump price of petrol from eighty-seven naira (N87) to one hundred and forty-five naira (N145) per litre. The fact that this act has had devastating effects on the lives of the majority of the Nigerian masses cannot be overemphasized. In Nigeria's petrol-dependent and petroldriven economy, this astronomical increase instantly precipitated huge increases in the costs of goods and services. And the victims are the already poor and long-suffering masses.

It should be stated that there was no notable nationally-organised resistance to this insensitive and draconian policy of the Buhari-led government. The workers' union, the Nigerian labour Congress (NLC) - with a largely compromised and ideologically bankrupt leadership - failed to respond in any significant way to the government's wicked actions. To this extent, an "ideological hegemony" appeared to have been attained by the government. "Ideological hegemony" is achieved by the ruling class in a society not so much to the extent that it is able to impose a uniform conception of the world on the rest of the society, but to the extent that it can articulate different visions of the world in such a way that their potential antagonism is neutralized (Madunagu, 1988 cited in Adetula, 1992: 333).

In an attempt to justify the removal of fuel subsidy, the government stated that it was deregulating the oil sector and that the subsidy scheme was fraudulent. It was also pointed out that deregulation would generate more funds for the government to invest in other key sectors of the economy. But deregulation is not all about the government arbitrarily fixing the price of petrol (or any other good for that matter), for in a pseudo-capitalist system which the Nigerian elites claim to practise in the country, that should be the job of Adam Smith's "invisible hands" of market forces of demand and supply.

According to Akpan Ekpo (2011: 27), a Nigerian Professor of Economics, the removal of oil subsidy is faulty even on theoretical grounds; on the demand side, there are millions of players but on the supply side there is a problem: some 80 per cent of the petroleum products used in the country is imported and only 20 percent is refined in the domestic market. Under such a scenario, Ekpo argues, it becomes a challenge to determine an appropriate market-determined price. Consequently, in his view, the issue of subsidy becomes suspect as it throws up a mountain of questions: What is the appropriate cost profile of pump price of petroleum? Why is the country still importing about 80 percent of petroleum products? Ekpo states that using this aspect to determine either the appropriate domestic pump price or the amount of subsidy involved remains a problem. Other questions include: What is the cost of inefficiency in the government-owned oil company (NNPC)? What is the cost of the refineries producing below installed capacity? What is the quality of infrastructure in the country? What is the quality of the provision of social services such as health and education, among others in the country? etc.

Professor Ekpo also contends that a wrong tinkering of the oil price (subsidy removal included) will trigger increases in the general price level - what economists call structural inflation, and this phenomenon, if allowed to occur, according to him, would affect other important macroeconomic variables such as the interest rates, nominal wages, investment and unemployment, thus making macroeconomic management of the economy difficult. He concludes that there is now no convincing reason for the removal of petroleum/oil subsidy until government properly reforms the oil and gas sector of the economy, reduce heavy 
reliance on petroleum revenue, set in motion policies and incentives for the construction of refineries, among others. Professor Ekpo made these points six years ago; they are as valid now as they were then.

While commenting on the increase of pump price of petrol by the Buhari-led administration, Eyekpimi (2016) lists what he/she regards as the "advantages" of the policy to include:

1. this new pump price will hopefully resolve the recurrent fuel scarcity crisis by ensuring availability of products as marketers will now be able to import product to the fullest capacity without government restrictions on import approval;

2. it will also help reduce hoarding, smuggling and diversion of petroleum products and help ensure product price and free market stability through private sector participation;

3. it will stabilize the labour market, enabling employment creation through new investments in private refineries, oil retailing, and loss of excess crude via gas flaring;

4. it will ensure competition in the industry and market forces will drive down the price of petrol in the long run as witnessed in the telecoms sector;

5. improvement in the power sector: the current fuel price will lead to the research for cheaper power generation alternatives; and

6. increase in government interests in other sectors: the subsidy removal will give government access to more funds for development of other sectors such as education, health, employment, transportation, etc.

The author also enumerates the disadvantages of the policy as follows:

1. increased cost of living: with the price of premium motor spirit (pms) increased, the economy will face a sudden surge of inflation. As inflation sets in, more Naira will purchase fewer goods causing depreciation in its value;

2. increase in transport cost: transportation cost has gone up as much as 300 percent since the N145/litre increase. This increase has caused a ripple effect on other sectors of the economy;

3. increase in the cost of small scale business services. These businesses depend on subsidized fuel to render services, as public electricity supply is not reliable;

4. increased cost of production; and

5. customer abuse.

Even a cursory glance at the above points would reveal that the adverse effects of the policy of subsidy removal in an underdeveloped socio-formation like Nigeria far outweigh whatever "gains" that are attributed to it. It should be remembered that between 2000 and 2007, the administration of Olusegun Obasanjo increased the pump price of petrol at least six times; in 2012, the Goodluck Jonathan government raised the price of fuel; and in 2016, the Buhari regime also increased the price of petrol. All these regimes argued that the "advantages" of subsidy removal - as listed above - would accrue to the country. Nigerians are still waiting for these "benefits".

It should be emphasized that the essence of governance is the promotion of people's welfare. As Rajesh Tandon (2009: 185) puts it, governance is about the systems and processes of mobilization and utilization of public resources for common public goods; therefore, it implies that various institutions and systems in the government are essentially concerned with determination and delivery of various public goods. Public policy, as Dewey (cited in Momoh and Quadri, 2015: 73) observed, has to do with "the public and its problems". The problems of the Nigerian public are legion: poverty, lack of social amenities (roads, electricity, hospitals, schools, rail transportation, etc), high level of unemployment, scandalous rates of inflation, etc., 
therefore, every public policy should be aimed at the promotion of the public good by tackling these problems facing the people, not by compounding them.

With the frequent increases in the price of petrol, the Nigerian ruling elites have turned crude oil - which is a blessing in other climes - into a curse on the lives of the Nigerian masses. What Nigerians suffer in the hands of the wicked and unproductive ruling class is different from what obtains in many other oil producing states. The information in the table below is illustrative

TABLE 1

Population and Petroleum Related Data on OPEC Members (As At 2011)

\begin{tabular}{|c|c|c|c|c|c|c|c|c|c|c|c|c|}
\hline $\mathrm{S} / \mathrm{N}$ & $\begin{array}{l}\text { OPEC } \\
\text { Memb } \\
\text { ers }\end{array}$ & $\begin{array}{l}\text { Popul } \\
\text { ation } \\
\text { (Milli } \\
\text { on) }\end{array}$ & $\begin{array}{l}\text { Prove } \\
\mathrm{n} \\
\text { Crude } \\
\text { Oil } \\
\text { Reser } \\
\text { ves } \\
\text { (billio } \\
\text { n } \\
\text { barrel } \\
\text { s) }\end{array}$ & $\begin{array}{l}\text { Crude } \\
\text { Oil } \\
\text { Produ } \\
\text { ction } \\
(1000 \\
\text { b/d) }\end{array}$ & $\begin{array}{l}\text { Crude } \\
\text { Oil } \\
\text { Expor } \\
\mathrm{t} \\
(1000 \\
\mathrm{b} / \mathrm{d})\end{array}$ & $\begin{array}{l}\text { Refine } \\
\text { ry } \\
\text { Capac } \\
\text { ity } \\
(1000 \\
\text { b/d) }\end{array}$ & $\begin{array}{l}\text { Outpu } \\
t \quad \text { of } \\
\text { Petrol } \\
\text { eum } \\
\text { Produ } \\
\text { cts } \\
(1000 \\
b / d)\end{array}$ & $\begin{array}{l}\text { Expor } \\
\text { ts of } \\
\text { Petrol } \\
\text { eum } \\
\text { Produ } \\
\text { cts } \\
(1000 \\
\text { b/d) }\end{array}$ & $\begin{array}{l}\text { Consu } \\
\text { mptio } \\
\mathrm{n} \quad \text { of } \\
\text { Petrol } \\
\text { eum } \\
\text { Produ } \\
\text { cts } \\
(1000 \\
\mathrm{b} / \mathrm{d})\end{array}$ & $\begin{array}{l}\text { Cost } \\
\text { of } \\
\text { Fuel } \\
\text { (pms) } \\
\text { Per } \\
\text { Litre } \\
\text { (USD) }\end{array}$ & $\begin{array}{l}\text { Cost } \\
\text { of } \\
\text { Diesel } \\
\text { Per } \\
\text { Litre } \\
\text { (USD) }\end{array}$ & $\begin{array}{l}\text { Mont } \\
\text { hly } \\
\text { Mini } \\
\text { mum } \\
\text { Wage } \\
\text { (USD) }\end{array}$ \\
\hline 1 & $\begin{array}{l}\text { Algeri } \\
\mathrm{a}\end{array}$ & 31.1 & 12.20 & 1,190 & 709 & 652 & 632 & 341 & 338 & 0.18 & 0.12 & 356 \\
\hline 2 & $\begin{array}{l}\text { Angol } \\
\mathrm{a} \\
\end{array}$ & 19.5 & 9.50 & 1,691 & 1,683 & 39 & 47 & 8 & 110 & 0.49 & 0.39 & 153 \\
\hline 3 & $\begin{array}{l}\text { Ecuad } \\
\text { or } \\
\end{array}$ & 14.3 & 7.21 & 476 & 340 & 188 & 185 & 28 & 220 & 1.47 & 0.89 & 473 \\
\hline 4 & Iran & 75.4 & $\begin{array}{l}151.1 \\
7 \\
\end{array}$ & 3,544 & 2,583 & 1,741 & 1,743 & 371 & 1,775 & 0.12 & 0.02 & 552 \\
\hline 5 & Iraq & 32.4 & $\begin{array}{l}143.1 \\
0 \\
\end{array}$ & 2,358 & 1,890 & 800 & 513 & 5 & 566 & 0.36 & 0.56 & 165 \\
\hline 6 & $\begin{array}{l}\text { Kuwai } \\
\mathrm{t}\end{array}$ & 3.6 & $\begin{array}{l}101.5 \\
0 \\
\end{array}$ & 2,312 & 1,430 & 936 & 893 & 632 & 260 & 2.07 & 1.88 & 1,028 \\
\hline 7 & Libya & 6.6 & 47.10 & 1,487 & 1,118 & 380 & 546 & 48 & 299 & 0.16 & 0.13 & 148 \\
\hline 8 & $\begin{array}{l}\text { Nigeri } \\
\mathrm{a}\end{array}$ & 167.0 & 37.20 & 2,559 & 2,464 & 445 & 249 & 23 & 259 & 0.43 & 1.00 & 120 \\
\hline 9 & Qatar & 1.7 & 25.38 & 733 & 586 & 80 & 133 & 322 & 116 & 0.20 & 0.27 & $\begin{array}{l}\text { Not } \\
\text { Availa } \\
\text { ble }\end{array}$ \\
\hline 10 & $\begin{array}{l}\text { Saudi } \\
\text { Arabi } \\
\text { a }\end{array}$ & 26.1 & $\begin{array}{l}264.5 \\
2\end{array}$ & 8,166 & 6,644 & 2,109 & 1,914 & 950 & 1,436 & 0.14 & 0.07 & 632 \\
\hline 11 & UAE & 4.7 & 97.80 & 2,324 & 2,103 & 466 & 355 & 188 & 238 & 0.37 & 0.51 & $\begin{array}{l}\text { Not } \\
\text { Availa } \\
\text { ble }\end{array}$ \\
\hline 12 & $\begin{array}{l}\text { Venez } \\
\text { uela } \\
\end{array}$ & 28.9 & $\begin{array}{l}296.5 \\
0 \\
\end{array}$ & 2,854 & 1,562 & 982 & 1,415 & 751 & 675 & 0.02 & 0.01 & 610 \\
\hline
\end{tabular}

Source: Ehi Oyabure (2011) “Analysis Of Fuel Subsidy Removal” available at www.saharareporters.com. Accessed on November 24, 2011

From the table above, it is clear that Nigeria is the country with the fourth highest cost of fuel (per litre) and the second highest cost of diesel (per litre) among OPEC members. The table also indicates that Nigeria has the lowest minimum wage (per month) among OPEC members. It is important to stress that in 2011 when the data in the above table was collected, the cost of fuel (per litre) in Nigeria was sixty-five naira (N65); currently, it is one hundred and forty-five naira (N145)! 
In view of the fact that oil is the most vital factor in Nigeria's socio-economic dynamics, the huge increase in the cost of this product by President Buhari automatically catalyzed unprecedented increases in the prices of goods and services - with asphyxiating effects on the lives of the masses. In August, 2016, Nigeria's Vice President, Yemi Osinbajo (cited in Baje, 2016) acknowledged that "governments have not been accountable to the people, otherwise policies should have roots in the real conditions of the people". But how does the Bretton Woods institutions-inspired policy of increasing the pump price of petrol - an increase of more than sixty percent - in an underdeveloped, petrol-dependent neocolonial economy like Nigeria improve the conditions of an already immiserized people? The anti-people nature of the policy of increasing the price of petrol can also be deciphered form the table below.

Table II

Costs of Selected Goods/Services - Before and After the Increase of Pump Price of Petrol in Nigeria

\begin{tabular}{|c|c|c|c|}
\hline $\mathrm{S} / \mathrm{N}$ & Good/Service & $\begin{array}{c}\text { Cost Before Increase of } \\
\text { Pump Price of Petrol } \\
\text { (Before May 2016) } \\
\text { (N) }\end{array}$ & $\begin{array}{c}\text { Cost After Increase of Pump } \\
\text { Price of Petrol } \\
\text { (After May 2016) } \\
\text { (N) }\end{array}$ \\
\hline 1 & 1 Bag of Rice & 10,000 & 22,000 \\
\hline 2 & $1 \mathrm{Bag}$ of Cement & 1,400 & 2,000 \\
\hline 3 & 1 Tin of Geisha (Tin Fish) & 80 & 200 \\
\hline 4 & $12.5 \mathrm{~kg}$ of Cooking Gas & 3,000 & 5,000 \\
\hline 5 & 1 Tin of Peak Milk & 90 & 200 \\
\hline 6 & 1 Tin of Clappa Tomato Paste & 150 & 300 \\
\hline 7 & Barbing of Hair (Male Adult) & 100 & 300 \\
\hline 8 & A Litre of Petrol & 85 & 145 \\
\hline 9 & $\begin{array}{l}\text { A Litre of Kerosene (used for cooking } \\
\text { by majority of Nigerians) }\end{array}$ & 150 & 280 \\
\hline 10 & 1 Fairly-Used 14-Rimmed Tyre & 3,500 & 8,300 \\
\hline 11 & 1 "Bic" Biro Pen & 30 & 60 \\
\hline 12 & 1 Ream of Printing Paper & 700 & 1,600 \\
\hline 13 & $\begin{array}{l}1 \text { Basin of Garri (A Popular Staple } \\
\text { Food In Most Nigerian Homes) }\end{array}$ & 2,500 & 6,000 \\
\hline 14 & A Cup of Groundnut & 40 & 120 \\
\hline 15 & $\begin{array}{l}1 \text { Packet (Small Size) of “Golden } \\
\text { Morn” (Children's Food) }\end{array}$ & 400 & 700 \\
\hline 16 & $\begin{array}{l}\text { Artemisinin-based Combination } \\
\text { Therapy (ACT) }\end{array}$ & 700 & 1,600 \\
\hline
\end{tabular}

Source: Obo, Omenka and Agishi (2017) - Field Study

From the above table, it is clear that the costs of goods and services have completely skyrocketed - even when people's income remains the same, and in some cases has even dwindled. In many parts of Nigeria, workers and pensioners are owed several months of unpaid salaries and pensions. The hardship and suffering in present-day Nigeria are unprecedented and palpable. During President Buhari's presentation of the 2017 national budget proposal to the parliament, Bukola Saraki, Nigeria's Senate President, and a key member of Nigeria's ruinous and avaricious ruling clique declared:

Mr. President, the feedback we get from visits to our various constituencies is that there is hardship in the land. We can see it and we can feel it. This situation, therefore, commands all of us as government to a greater sense of urgency... Our people must see that the singular pre-occupation of government is the search for solution to the current economic hardship, and the commitment to ease their burden... (cited in Yesufu, Itua and Orji, 2016: 13). 
The hypocrisy and gross dishonesty inherent in the above assertion notwithstanding, it indicates that those who misgovern Nigeria know that the Nigerian people are not smiling.

Like its predecessors, the Buhari government tried to defend its policy of increasing the price of petrol; it pointed out that the policy would generate funds for development; stabilize fuel supply; eliminate smuggling of fuel out of the country; and it was needful for the "deregulation" of the oil sector. But "to continue to recycle kindergarten logic" to justify the hardship visited upon the masses by the policy of subsidy withdrawal "amounts to a tragic insult on the collective intelligence of Nigerians"(Director, 2005: 3).

Again, like the regimes before it, the Buhari administration asked Nigerians to make sacrifices for the development of the country. But as Pius Adesanmi (2016) has aptly shown, wherever it has worked in history as in mythology, sacrifice has always been democratic and collective, and the first to sacrifice for the collective good has always been the leadership; this is how the leadership comes to acquire the symbolic validity to preach sacrifice to the people and to mobilise the theme of the darkness just before the light at the end of the tunnel as a valid pathway to national redemption. Adesanmi also points out that where a leadership takes the lead and adapts her material needs and tastes to the imperative of sacrifice, she acquires the legitimacy to inspire the people to sacrifice; sacrifice becomes democratic when the effects of hardship are equally felt, and sacrifice becomes inspiring when a people's leadership is the first to take the plunge by adapting her taste to the imperatives of the moment.

Professor Adesanmi also stated that no nation has ever succeeded in which the leadership summons the people to sacrifice while bluntly refusing to forego even the most minimal fragment of her own privileges according to the exigencies of the moment. In his words, ...no leadership has ever successfully mobilized the people to sacrifice while nestled in obscene comfort, ostentation, debauchery, and carnivalesque. Only sacrifice which is democratic is legitimate. Only sacrifice which is democratic should be morally and ethically supported. Only sacrifice which is democratic can mobilise the people.

While President Muhammadu Buhari and officials of his government ask the masses for sacrifice, they (the government officials) enjoy immense comfort and luxury funded by the Nigerian people. For instance, in the 2017 national budget estimates, 100.8 million is allocated for the purchase of canteen and kitchen equipment, while foodstuff and catering materials will gulp $\$ 123$ million and refreshment and meals $\$ 97.2$ million; $\$ 80.3$ million was voted for the same purpose in 2016 budget, while, in the preceding year, it was $\$ 237.3$ million, and the same 2016 budget contained votes of $\$ 92.6$ million and $\$ 94.3$ million for food and catering materials and refreshment and meals respectively (Editorial, The Punch, January 19, 2017). These are all for the presidency only.

Moreover, in 2017, the Presidency has earmarked for itself $\$ 100.8$ million for the purchase of "motor vehicles" and another N97.2 million to be spent on acquisition of buses; this same purchase of motor vehicles and buses also attracted \$599 million and $\$ 278$ million respectively in 2016, and the same 2016 budget contained items such as the purchase of five BMW cars at $\$ 40$ million each and five Prado or Toyota Land Cruiser Jeeps (SUVs) at $\$ 28$ million each (all totaling $\$ 340$ million); 10 16-seaterHiace buses, 10 33-seater Coaster buses and one utility pick-up van, all valued at $\$ 278$ million (Editorial, The Punch, January 19, 2017). It is instructive to note that President Buhari also has at his disposal - for his comfort and pleasure - the largest Presidential Fleet of aircrafts in the world. 


\section{CONCLUSION}

This essay has tried to draw attention to the fact that different countries of the world (including the developed ones) have designed different forms of subsidy schemes for the benefit of their people. A programme of subsidy, if well managed and properly targeted, can serve as a tool for the promotion of public welfare. According to Moses Ochonu (2016), it is not subsidy per se that is the problem but rather how it is administered, what product is being subsidized, how much the subsidy costs, whether it is sustainable and for how long, and its multiplier effect on the economy. In his words, if you can afford it, you can use a temporary, transparent subsidy regime to support the affordable supply of a strategic national product while you work on a permanent solution, and if there is any product that is worth subsidizing in Nigeria, it is oil.

It is also clear from the foregoing passages that the increase in the price of petrol by the Buhari-led government has compounded the economic woes of the majority of the Nigerian people. There is no doubt that "no one cares for democracy on an empty stomach", and "we must not forget that a democratic culture and stability cannot thrive in a society where there is abject poverty" (Elaigwu, 2004: 64).

As a presidential candidate, Muhammadu Buhari was regarded by many Nigerians as a symbol of hope, positive change and high expectations. But so far, as a president, he has disappointed many through his hardship-inducing policies. As Abimbola Adelakun (2017) stated in an interesting analogy, Buhari seems to have become a typology of Baal, the god in which prophets - Professors, columnists, intellectuals, pastors, political advocates, poets, civil society activists, thinkers, man on the street, and millions of voters who wanted a change - put their trust. According to Adelakun, people put themselves out for Buhari; some folks invested the credibility they had spent years garnering to vouch for Buhari; but like Baal, as feelers from across the country these days indicate, Buhari has let them down spectacularly.

We agree with the view that the quality of governance is not determined by how much you stash away in foreign reserves but by the quality of life, standard of living and depth of comfort of the people (Director, 2005: 3); any government that does not promote these values or ideals through its policies and programmes is a failure.

\section{References}

Adelakun, Abimbola (2017). "Buhari and the Prophets of Baal” in the Punch, February 9.

Adesanmi, Pius (2016). "It Will Get Worse Before It Gets Better" available at www.sahrareporters.com. Accessed on May 14, 2016

Adetula, Victor A. (1992). "The Political Economy Of Democratic Transition In Nigeria, 1985-1991" in B. Caron, A. Gboyega and E. Osaghae eds., Democratic Transition In Africa. Ibadan, Nigeria: Centre de Recherchesd'Echangeset de Documentation Universitaire, CREDU.

Ajala, Dolapo (2012). "The Goodluck Present - An Analysis on Oil Subsidy" available at www.saharareporters.com. Accessed on January 12, 2012

Ajayi, S. Ibi (2003). Nigeria and the Political Economy of Development: The Dreams, the Myth and the Reality. Ibadan, Nigeria: The Nigerian Economic Society

Akinloye, Bayo (2017). “Buhari Not Competent To Govern Any Country - Kperogi” in The Punch, January 29.

Anazodo, Rosemary, Uche Ezenwile and D. C. Chukwurah (2014). "The Impact of Oil Subsidy Removal on Infrastructural Development in Nigeria (2000-2012)" in Public Administration Research, Vol. 3, No. 1.

Baje, Ayo Oyoze (2016). “Do They Know We Are Suffering?” in the Punch, August 5 
Boladale, Adekoya (2016). "How Buhari's Government Is Weaponizing Hunger" available at www.saharareporters.com. Accessed on December 29, 2016

Director, Osa (2005). "Between Obasanjo and God" in Insider Weekly, September 12

Efo, Nkeneke (2002). “Hard Times” in the News, November 25.

Ekpe, Aniekan E. (2003). “The IMF, Price Deregulation and Third World Development: An Empirical Analysis of the Withdrawal of Petroleum Subsidy on Nigeria's Economy" in Journal of Globalization and International Studies, Vol. 1, No. 1, July-December

Ekpo, Akpan H. (2011). “The Petroleum Subsidy Palava” in TELL, July 18.

Elaigwu, J. Isawa (2004). The Challenges of Nation-Building in the Twenty-First Century: The Nigerian Experience. Calabar, Nigeria: University of Calabar Press

Exenberger, Andreas (2013). "The Phenomenon Of Globalization: A First Orientation" in Philipp Strobl and Manfred Kohler eds., The Phenomenon Of Globalization: A Collection Of Interdisciplinary Globalization Research Essays. Frankfurt: Peter Lang GmbH InternationalerVerlag der Wissenschaften.

Eyekpimi, Omawumi (2016). "Fuel Subsidy Removal And The Nigerian Economy: Advantages and Disadvantages" available at www.infoGuideNigeria.com. Accessed on October 25, 2016

Gaskia, Jaye (2011). "Governing By Stealth: Exploding The Myths around the Oil Subsidy Removal/Fuel Price Hike Agenda of the Nigerian Government", available at www.saharareporters.com. Accessed on December 28, 2011

George, Taiwo (2015). "Buhari: No Good Reason to Remove Fuel Subsidy", available at www.thecable.ng-2015. Accessed on July 13, 2015

Majekodunmi, Aderonke (2013). "The Political Economy of Fuel Subsidy Removal in Nigeria" in International Journal of Management and Social Science Research (IJMSSR), Vol. 2, No. 7, July

Momoh, Abuakar and Maryam Quadri (2015). "Values in Analysis: Some Considerations on the Pitfalls of Public Policy Analysis". In Celestine Oyom Bassey and Uno Ijim Agbor eds., Public Policy and Politics in Nigeria: A Critical Discourse. Lagos, Nigeria: Concept Publications Limited

Obo, UgumanimBassey and Moses A. Abua (2008). "Democracy And The Dialectics Of Mass Poverty: The Nigerian Experience (1999-2006)" in LWATI: A Journal of Contemporary Research, Vol. 5, June

Obo, UgumanimBassey, Maurice Ayodele Coker and Jacob IbaOmenka (2014). "The State As An Instrument Of Primitive Accumulation: The Nigerian Example, 1999-2013" in Journal Of Law, Policy And Globalization, Vol. 26

Obo, Ugumanim Bassey, Felix Onen Eteng and Maurice Ayodele Coker (2014).“Public Opinion And The Public Policy Making Process In Nigeria: A Critical Assessment” In Canadian Social Science, Vol. 10, No. 5, October 31.

Ochonu, Moses E. (2016). “The Fuel Supply Problems: Don't Dump It on Nigerians” available at www.saharareporters.com. Accessed on May 13, 2016

Ogundipe, Olufemi (2009). "Where Has All the Money Gone?" in the News, December 7

Ojekheta, K. O. (2010). “Epistemological Vandalism Of Learning In Africa: A Paradigm Shift From Traditional Banking Education To Libertarian, Dialogic And Problem-Posing Education" in A. O. Agwuele, U. M. Nwankwo and O. Akinwumi eds., Multidisciplinary Perspectives On Overcoming The African predicament. Berlin: Mediateam IT Publishers.

Oyabure, Ehi (2011). "Analysis of Fuel Subsidy Removal" available at www.saharareporters.com. Accessed on November 25, 2011.

Sote, Lekan (2012). "Vexing Issue of Fuel Subsidy" in the Punch, November 6.

Tandon, Rajesh (2009). "Challenging The Professionals: The Imperative Of Democratic Governance Today" in Adult Education And Development, 72.

"Text of President Buhari's Anniversary Speech" n.a. available at www.punchng.com/text-president...

The Bible, revised standard version

The Punch, January 19, 2017. “Discarding Wasteful Substances In 2017 Budget”, an editorial.

Timamy, M. H. Khalil (2007). The Political Economy of Technological Underdevelopment in Africa:

Renaissance Prospects, Global Tyranny, and Organised Spoliation. Lagos, Nigeria: Centre For Black and African Arts and Civilization (CBAAC)

Uchendu, V. C. (2015). "A Theory of Public Policy" in Celestine OyomBassey and Uno IjimAgbor eds. cited above 
Obo, U. B., Omenka, J. I., Agishi, T. V., \& Coker, M. A. (2017). Fuel Subsidy Removal And The Ubiquity Of Hardship In Nigeria: President Buhari And Lessons From King Rehoboam. Advances in Social Sciences Research Journal, 4(14) 113-126.

Ukah, Ndubuisi (2016). "Nigeria at an Economic Crossroads" in the Guardian, September 9.

Yesufu, Kemi, Fred Itua and Ndubuisi Orji (2016). "Saraki To Buhari: There's Hardship in Nigeria”, in Daily Sun, December 15. 